DOI: $10.15393 /$ j9.art.2019.6181

УДК 801.733

Наталья Александровна Тарасова

(Санкт-Петербург, Российская Федерачия)

nsova74@mail.ru

\title{
Проблемы подготовки реального комментария (на материале романа Ф. М. Достоевского «Идиот»)
}

Аннотация. Статья посвящена теоретическим и практическим вопросам, возникающим при подготовке реального комментария к произведениям Ф. М. Достоевского. В работе рассматриваются традиционные и современные подходы к комментированию художественных произведений, приводятся варианты классификации филологических комментариев разных типов, выделяются разновидности, которые имеют значение для исследования творчества Достоевского. На материале романа «Идиот» (рукописные редакции и печатный текст) рассматривается вопрос о задачах, предмете, содержании и пределах реального комментария к художественному произведению. Анализируются проблема толкования слова с учетом смыслового контекста, вопросы комментирования имен реальных исторических лиц и персонажей, аллюзий на определенную реально-историческую систему идей, библейских и литературных интертекстов, в том числе автореминисценций. В результате выполненного анализа уточнен и дополнен реальный комментарий к роману Достоевского «Идиот».

Ключевые слова: Достоевский, русская литература, проблемы комментирования художественного текста, реальный комментарий, библейские и литературные интертексты, автореминисценции

Об авторе: Тарасова Наталья Александровна - доктор филологических наук, ведущий научный сотрудник, Института русской литературы (Пушкинский Дом) РАН (199034, Российская Федерация, г. Санкт-Петербург, наб. Макарова, 4)

Дата поступления: 05.04.2019

Дата публикации: 09.09.2019

Для цитирования: Тарасова Н. А. Проблемы подготовки реального комментария (на материале романа Ф. М. Достоевского «Идиот») // Проблемы исторической поэтики. - 2019. - Т. 17. - № 3. - С. 149-185. DOI: 10.15393/j9.art.2019.6181

B настоящее время проблеме комментирования художественных произведений уделяется существенное исследовательское внимание, что объясняется появлением новых 
издательских проектов и осмыслением принципов научного, в том числе академического, комментария (см.: [Захаров, 2012, 2013]).

Теория и практические вопросы комментирования разрабатываются достаточно давно. Б. В. Томашевский, как известно, выделял семь типов научного комментария: 1) историко-текстовый и библиографический, 2) редакционно-издательский, мотивирующий выбор текста, 3) историко-литературный, 4) критический, 5) лингвистический, 6) литературный, 7) реальный, или исторический [Томашевский: 207]. Как видно из этой классификации и последующих объяснений, исследователь пытался разграничить историко-литературный, литературный и реальный комментарии. Под историко-литературным комментарием Томашевский понимал описание «внешней судьбы» произведения, в том числе в биографическом аспекте, когда произведение рассматривается «в жизни его автора», «в общей эволюции творчества данного автора и, наконец, в общей эволюции литературы его времени» [Томашевский: 199]. К сфере литературного комментария исследователь отнес анализ поэтики произведений. Реальный комментарий Томашевский определил как категорию «самую ответственную и требующую наибольшего критицизма». Основная задача такого комментария - предоставление «сведений о современных автору лицах и событиях» [Томашевский: 208, 210]. Текстологический, лингвистический, историко-литературный и реальный комментарии стали основными в научных изданиях литературных текстов.

При обращении к конкретной комментаторской практике становится очевидным ряд проблем. И. А. Пильщиков обращает внимание на такой критерий комментирования, как широта охвата материала. Применительно к историко-литературному комментарию закономерно возникают вопросы: «Насколько широко должен быть охвачен литературный контекст? Необходимость отметить прямые цитаты самоочевидна. А реминисценции, аллюзии, другие виды подтекстов? Как вообще провести границу между явлениями, связанными между собой типологически, и явлениями, связанными между собой генетически? Отсюда - самая насущная практическая проблема: в каком объеме включать параллели» 
[Пильщиков: 44]. При подготовке реального комментария «главный вопрос: насколько широко и связно должен быть представлен историко-бытовой фон? <...> Ведь в конечном счете комментарий объясняет текст, а не контекст, и потому должен быть преимущественно ориентирован на сам текст и его смысл» [Пильщиков: 44-45].

Широта материала зачастую приводит к некоторой размытости границ между разными типами комментария. Так, в 30-томном Полном собрании сочинений Достоевского ${ }^{1}$ традиционно разграничиваются историко-литературный (статейный) комментарий к произведениям писателя и реально-исторический, но фактически в состав последнего входят не всегда только сведения, касающиеся исторических реалий, но и литературные параллели, и лингвистические объяснения, и многое другое.

Определяя принципы комментирования текста, нельзя не согласиться с мыслью о том, что «комментарий, прежде всего, должен следовать одному из главных требований античной риторики - уместности (лре́ло v, decus)» [Монологи о комментарии: Л. Г. Степанова: 122]². По мнению Ю. В. Манна, «все зависит от формы подачи, то есть от стиля, то есть от постулата объективности <...>. Нужен, если снова употребить современное речение, “информационный повод”. Проблемы поэтики, интерпретации затрагиваются в аспекте истории творческого замысла, рецепции читателей, критики и т. д. Значит, можно уточнить: это не только “повод”, не только внешняя зацепка, но внутреннее движение материала» [Манн: 108-109] $]^{3}$ В основе такого комментария находится «именно разъяснение того, что требует разъяснения. Комментатор не стоит над читателем с указкой, со строгими наставлениями, как следует понимать текст; он скорее предоставляет читателю необходимый для понимания материал» [Манн: 109-110]. Подчеркнем, что при комментировании текста, в частности при подготовке реального комментария, исследователь учитывает не только фактографию, имеющую отношение к исторической реальности, но и особенности мировоззрения автора, жанровую структуру произведения, стиль повествования, речевые характеристики персонажей, 
потому что названные условия отражают специфику художественного преломления фактов действительности в творческом сознании писателя. Согласно логике «внутреннего движения материала», в реальном комментарии в ряде случаев могут иметь значение сведения, касающиеся названных аспектов анализа.

Существенным представляется вопрос о необходимости осмысления самого «статуса реалии» - например, в случае комментирования «символистских (или даже - символических, каковы практически все вершинные произведения искусства) текстов». По мнению Т. А. Касаткиной, комментарий, сохраняющий «позитивистский статус реалии, переводит в другой статус сам комментируемый текст. Он - даже будучи самым отрывочным и непоследовательным (на что он, впрочем, практически обречен, потому что любая связность это движение в сторону интерпретации) - задает для текста uные реперные точки, чем те, которые имел в виду автор, и это радикально сбивает восприятие читателя» [Касаткина, 2018: 182]. Это действительно значительная проблема, в том числе и при комментировании текстов так называемых писателей-«реалистов». Реальный комментарий, не учитывающий художественную специфику материала и особенности авторского мировоззрения, приводит к бездумной фиксации тех или иных фактов без попыток осмыслить и показать их значение в авторском сознании и в конкретном месте комментируемого произведения.

Для определения принципов комментирования небесполезен опыт переводческого комментария, имеющего иную типологию, которая несколько отличается по структуре от типологии академического комментария, но представляет интерес по своему содержанию и функциям. По замечанию Н. Н. Коробейниковой, «формально и функционально комментарий представляет собой мета-текст (“текст в тексте” и “текст о тексте”). Метатекстуальность комментария открывает многоканальность восприятия основного текста, снимает “линейность" его прочтения за счет активизации различных семиотических кодов или сфер. Охват семиотических сфер и, как следствие, глубина семантизации комментируемых единиц различна: 
комментарий эксплицирует семантическую сферу, связанную с функционированием комментируемой языковой единицы в разных контекстах (сфера ядра значения знака), межтекстовую семиотику (интертекстуальная сфера) и реальность, связанную с образом мира писателя (сфера идиолекта писателя)» [Коробейникова: 6]. Собственно, названные характеристики комментария определяют и его типологию.

Основная функция комментария любого типа «герменевтическая», обеспечивающая понимание текста [Коробейникова: 6, 9]. Энциклопедический [Коробейникова: 10], или словарный [Казакова: 169-171], тип комментария имеет целью объяснение непонятного, это своего рода «глоссарий, минисловарь к тексту» [Коробейникова: 10]. Среди разновидностей такого комментария для нас наиболее значим контекстуально ориентированный, содержащий информацию, необходимую для понимания авторских интенций. Этот комментарий «помогает раскрыть замысел автора, дать характеристику персонажа, увидеть событие или действующее лицо через призму описываемого времени, прочитать за текстом, между строк, то, что было известно и понятно современникам автора» [ТерМинасова: 115]. Сохраняет актуальность такая разновидность словарного типа, как просветительский комментарий, ориентированный на раскрытие «затекстового пространства», информирующий читателя о реалиях или культуронимах в целях их пояснения [Гаспаров: 72], [Коробейникова: 11], [Казакова: 172-173]. Чрезвычайно важен идиолектный комментарий, который призван раскрыть авторскую картину мира, «настраивает на понимание текста с учетом личностных смыслов авторской концептосистемы» [Коробейникова: 10]. Кроме того, имеет значение тип интертекстуального комментария [Коробейникова: 12], посвященного установлению источников интертекста, соотнесению их с комментируемым текстом и объяснению смысла этих литературных и иных параллелей [Гаспаров: 70-71]. Названные типы используются в историколитературном и реальном комментарии, в том числе к произведениям Достоевского.

Особой проблемой является «отражение в комментарии языковой личности автора и комментатора». Верна мысль о том, что информация комментария, направленная на раскрытие 
идиостиля писателя, «вскрытие пристрастий, образов, опыта, т. е. всего того, что формирует кониептуальную систему автора, помогает осознать мотивировку выбора формы для представления авторского смысла» [Коробейникова: 19]. Обычно подчеркивается установка на объективность, беспристрастность, стилистическую нейтральность комментаторской работы, однако на практике исследовательские комментарии всех типов и разновидностей, будучи результатом творческого, эвристического труда, не могут не выражать авторские подходы к истолкованию комментируемого текста и к форме подачи информации, что «обусловливает субъективность и принципиальную вариативность статей комментария, их динамичность, проявляющуюся как нетождественность подобным статьям в словарях или других комментариях» [Коробейникова: 20].

А. И. Рейтблат обращает внимание на изменение комментаторского статуса в эпоху развития цифровых технологий. Исследователь считает, что «социокультурные перемены, порожденные как социальными, так и текстологическими причинами, проблематизируют деятельность комментатора, ставят его перед необходимостью вновь дать ответ на вопросы “Что комментировать?”, “Для кого комментировать?”, “Как комментировать?” [Рейтблат: 89]. Для современного читателя, пользующегося Интернетом, «текст через поисковые системы и ссылки сразу же включается в широчайший интертекстуальный контекст» [Рейтблат: 89]. Однако сложно согласиться с утверждением, что при указанных условиях в эпоху Интернет-технологий «сразу же отпадает потребность в комментарии, излагающем сведения, содержащиеся в распространенных энциклопедиях, справочниках, библиографических указателях. Ведь наряду с ростом объема оцифрованных текстов совершенствуются и поисковые системы, которые в ближайшем будущем позволят легко выйти на наиболее авторитетную и достоверную информацию» [Рейтблат: 89]. Во-первых, в словарных статьях, особенно этимологических, одно и то же слово может комментироваться совершенно по-разному; во-вторых, комментарий как система объяснений, адресованных читателю, вряд ли предполагает 
по своей форме самостоятельное обращение читателя к различным источникам, даже если они размещены в сети Интернет, - читатель не обязан и едва ли пожелает проделывать такую работу, он вправе рассчитывать на готовый результат, предложенный специалистами. Поэтому речь здесь стоит вести, прежде всего, о том, что Интернет-технологии предоставляют как читателям, так и исследователям более широкий спектр возможностей для получения и для представления информации.

Обратимся к некоторым примерам - на материале романа Достоевского «Идиот».

При работе со словарным комментарием очевидной становится проблема толкования слова с учетом смыслового контекста. Так, в начальных сценах романа «Идиот» о князе Мышкине сказано, что он появился в вагоне поезда, держа в руках «тощий узелок из старого, полинялого фуляра, заключавший, кажется, всё его дорожное достояние» $(8,6)$. Комментарий ПСС лаконичен: «...из старого, полинялого фуляра... - Фуляр (франи. foulard) - легкая шелковая ткань» $(9,427)$. Это пример комментария «из словаря», поясняющего значение непонятного слова, в данном случае заимствования. Однако неясным остается контекстуальное значение слова, а здесь оно возможно, так как фуляр - слово многозначное. Первое - именно то, которое указано в ПСС. Но фуляром могли называть и платок (носовой, шейный, головной) из фуляровой ткани ${ }^{4}$. По справедливому замечанию В. Н. Алёкина (см.: [Алёкин]), в данном случае вероятнее второе значение, на что указывает подобное словоупотребление в романе «Бесы»: «Он закрыл глаза своим красным фуляром...» $(10,331)$; ср. в «Шинели» Н. В. Гоголя: «Он вынул шинель из носового платка, в котором ее принес...»5. «Фуляровый платочек, накинутый на голову» упоминается и в другой сцене романа «Идиот» $(8,493)$. Данный пример свидетельствует о том, что не сто́ит ограничивать реальный комментарий приведением лаконичных словарных сведений, а если их приводить, то полностью - учитывая другие значения слова и соотнося их с содержанием комментируемого контекста. 
Есть случаи, когда необходимо прояснить этимологию слова, и это не формальное предоставление словарной информации, а способ раскрыть тот или иной смысловой контекст в произведении. Так, в романе «Идиот» используется слово «воксал», причем прижизненные публикации, как и черновые рукописи, содержат только такой вариант написания, и это важно для понимания того, о чем говорят герои, например, в таких случаях: «Ты куда везти-то хотел? - В Екатерингоф...» $(8,142)$, «...после ужасной оргии в Екатерингофском воксале...» $(8,150)$, «В Павловском воксале...» $(8,286)$. Имеется в виду не вокзал в современном понимании, а место увеселений. Существуют различные этимологические объяснения слова «воксал». Bo-первых, оно возводится к англ. Vauxhall, происходящему «от собственного имени Vaux и hall - “зал” (ср. мюзик-холл), по имени Джейн Вокс (XVIIв.), владелицы загородного сада близ Лондона (для концертов, танцев, для карточной или иных игр, место увеселений, гулянья и т. п.)» ${ }^{6}$. Во-вторых, указана параллель слова «воксал» с лат. vox - голос7. Вариант «вокзал» утвердился в связи с тем, что Павловский музыкальный воксал «был расположен рядом с помещением одной из первых в России железнодорожных станций, название начали переносить и на нее» $(9,437)$.

При комментировании слов Келлера «произошел весь английский бокс» $(8,291 ;$ в ПСС комментарий к ним отсутствует) следовало бы указать на повторяемость авторского словоупотребления просторечного глагола «происходить» в значении «изучать, осваивать, познать». Слово запомнилось писателю в годы каторги и нашло отражение в «Сибирской тетради», ср.: запись № 269 «Все чины произошел» (ПСС$2,4,279)$; в «Селе Степанчикове и его обитателях»: «Всезнай! всю подноготную знает, все науки произошел!» (ПСС-2, 3, 27); в черновом автографе «Преступления и наказания»: «Были студентом или происходили ученую часть» (в ПСС слово ошибочно прочитано как «проходили» $-7,100)$; «Братьях Карамазовых»: «...в ту самую минуту всю истину произошел-с», «Как вы во всем столь умны, как это вы во всем произошли?» $(14,187,204)$. 
В предыдущем примере из романного текста воспроизводится значение, существующее и закрепленное в русском языке. Но есть случаи авторского переосмысления традиционных языковых значений. Так, в реплике Ипполита Терентьева «Ну, кто же не сочтет меня за сморчка, не знающего жизни, забыв, что мне уже не восемнадцать лет...» $(8,327)$ слово «сморчок», имеющее просторечный оттенок и контекстуально переносный смысл, если и соотносится с традиционными значениями «тщедушный на вид человек» ${ }^{8}$, «маленький, невзрачный или старый, морщинистый человек» ${ }^{9}$, то не в первую очередь. Скорее, в слове «сморчок» в данном контексте подчеркивается значение «невзрослый», «незначительный по жизненному опыту». Нетипичное употребление слова «тунеядцев» отметил В. Н. Алёкин (см.: [Алёкин] $)^{10}$, имея в виду рассуждения Лебедева: «Один из таких тунеядцев, приближаясь к старости, объявил сам собою и без всякого принуждения, что он в продолжение долгой и скудной жизни своей умертвил и съел лично и в глубочайшем секрете шестьдесят монахов и несколько светских младенцев...» $(8,312)$. Указанное слово в XIX в. имело то же значение, что и сейчас: бездельник, живущий на чужой счет ${ }^{11}$. Однако смысловой контекст, в котором оказывается это слово в романе «Идиот», предполагает значение «паразит», людоед в переносном смысле.

В следующем случае необходим комментарий к авторскому использованию устойчивого оборота. В рассказе генерала Иволгина о Наполеоне используется эпитет: «...он бросил на меня свой орлиный взгляд...» $(8,413)$. Выражение «орлиный взгляд» упоминается в словаре М. И. Михельсона, где поясняется значение прилагательного: «сверкающий, острый, проницательный» ${ }^{12}$. Такой эпитет встречается в романе М. Н. Загоскина «Рославлев, или Русские в 1812 году» $(1830)^{13}$. И это же определение, характеризующее Наполеона, использовал Александр Дюма-отец в книге «Наполеон» (глава «Наполеон на острове Эльба и 100 дней» - «Napoléon a l'île d'Elbe et les cent jours»): "Quoiqu'il suivît probablement de son regard d'aigle les événemens européens, Napoléon était donc, en apparence, entièrement soumis à sa fortune» («Возможно, когда орлиный взгляд Наполеона следил за развитием европейских событий, 
он казался внешне полностью смирившимся с судьбой») $)^{14}$. В этом случае, за отсутствием точных данных об источнике выражения, правильнее было бы рассматривать это словосочетание как речевое клише, встречающееся у разных авторов в качестве одной из описательных характеристик Наполеона Бонапарта.

Довольно часто простой словарный комментарий недостаточен из-за необходимости пояснять содержание целой сцены. Так, в сцене знакомства князя Мышкина с семейством Епанчиных генерал произнес фразу: «-И вдобавок дитя совершенное, с ним можно еще в жмурки играть» $(8,45)$. Слово «жмурки» здесь использовано в его прямом значении («детская игра, в которой один из участников с завязанными глазами ловит других» $\left.{ }^{15}\right)$. Но нуждается в комментарии реакция слушателей. Лизавета Прокофьевна, услышав эту фразу, задала вопрос, словно бы не понимая сказанного: «- В жмурки играть? Каким образом?». Аглая в этот момент начала сердиться («с досадой перебила»), Аделаида «не выдержала и рассмеялась». Через вопрос Лизаветы Прокофьевны и реакцию ее дочерей здесь, возможно, обыгрывается то значение, которое бытовало в XVIII-XIX вв.: жмурки как «игра любовная», «предсвадебная», - тем более что далее в романе мотив женитьбы князя Мышкина, то на Настасье Филипповне, то на Аглае, становится сквозным. По наблюдению К. А. Богданова, И. П. Сахаров в «Сказаниях русского народа» (1836-1837) описывает игру в жмурки «как русскую, хотя и очевидно, что в своем описании он близок не столько народной традиции, сколько традиции галантных забав “высшего света"» (см. подробнее: [Богданов: 135-136]): «Жмурки, или Слепой козел, есть игра домашняя, игра девушек и молодых мужчин, в большие зимние вечера. Девушки, с завязанными глазами, как бы лишенные зрения, стараются более поддаваться в руки любезных молодых мужчин, а о мужчинах и говорить нечего. Влюбленные, под видом оплошности, только одни и играют во весь вечер эту игру, тогда как другие только посмеиваются их незнанию прятаться от поисков Козла. Нет сомнения, что эту игру изобрела любовь: ведь наши предки любили не хуже нас» ${ }^{16}$.

Отсутствует комментарий к реалии, упомянутой в подготовительных материалах к роману «Идиот»: «Известие, что 
сегодня у Князя завтрак. Смотреть купленный кабинет редкостей. Стоил денег» $(9,225)$. Кабинет редкостей - это калька с англ. Cabinet of curiosities, нем. Wunderkammer, Kunstkammer (Кунсткамера). Первоначально так называли шкаф-кабинет, поздне́е - помещение для хранения разнообразных коллекций. Кабинеты редкостей известны в Европе с XVI в., а в XVII столетии обрели популярность, став своего рода прообразом современных музеев. Эта популярность объясняется «интересом к античности, географич<ескими> открытиями, первыми достижениями эмпирич<еской> науки». Вначале кабинеты редкостей появлялись во дворцах, со временем коллекции стали включать «предметы искусства, драгоценности, различные диковинки». По примеру дворцовых создавались «частн<ые> кабинеты редкостей в домах знати, богатых горожан, ученых» ${ }^{17}$. Кабинет редкостей могли себе позволить состоятельные люди; упоминание о нем в набросках к роману связано с мотивом получения главным героем наследства, что подтверждается и последующей записью: «Денег Князь получил больше, чем ожидали» $(9,225)$.

Комментирование имен реальных исторических лиц также достаточно сложная задача, потому что, во-первых, ее решение зависит от конкретных источников, положенных в основу комментария и могущих содержать разнящуюся и противоречивую информацию, а во-вторых, в силу неясности или информационной недостаточности комментируемого контекста, может быть потенциально вариантным. В этом случае возникает проблема полноты отражения информации. Думается, что реальный комментарий при указанных условиях должен отражать хотя бы основные версии истолкования имени или, при точно установленных ошибочных истолкованиях, указания на ошибки и верный вариант. Так, имя игумена Пафнутия, упоминаемого Мышкиным, комментируется в ПСС с неточностями - он назван «основателем Авраамиевой чухломской верхней пустыни на реке Виге (XIV в.)» $(9,431)$ со ссылкой на книгу П. М. Строева «Списки иерархов и настоятелей монастырей Российския церкви» (СПб., 1877. С. 869). Однако основателем этой пустыни считается преп. Авраамий Галичский (Чухломской, Городецкий), а Пафнутий был его 
учеником, поставленным на игуменство в Верхнем Собора Пресвятой Богородицы монастыре [Дорофеева: 36, 54] на реке Виге (ныне Костромская обл., Чухломский р-н, с. Коровье). Г. Н. Крапивин отметил, что и герой романа неточен в пояснениях, говоря, что Пафнутий «правил пустынью на Волге» $(8,46)$ : Вига является правым притоком реки Унжа, впадающей в Волгу [Крапивин: 146]. Игумена Пафнутия упоминал Р. В. Плетнев, имея в виду задачу создания «положительного типа», «первым опытом» решения которой, по мнению исследователя, был роман «Идиот» [Плетнев: 251-252, 387]. В «Словаре личных имен у Достоевского» (сост. под общей редакцией А. Л. Бема) указан другой Пафнутий: «Пафнутий, игумен (Боровский, в мире Парфений, ум. 1478)» ${ }^{18}$, что не соответствует упоминанию в романе «четырнадцатого столетия»: преп. Пафнутий Боровский основал монастырь в XV веке в Калужской епархии ${ }^{19}$. В научной литературе указана также литературная параллель с «игуменом Пафнутием» из пушкинского «Бориса Годунова», настоятелем Чудова монастыря [Крапивин: 148-151].

Даже при комментировании реальных исторических имен, как видим, возникают литературные параллели. Если же говорить о комментарии к именам (фамилиям) персонажей, то в таких случаях реальность (отсылки к прототипам) еще явственнее вступает во взаимодействие с художественным вымыслом, и возникает вопрос о пределах и объеме комментирования художественных образов в реальном комментарии. Это касается, к примеру, зоолексем в фамилиях героев Достоевского. В ПСС нет реального комментария к фамилии Птицын, а в статейном (историко-литературном) комментарии приводится сноска, отсылающая читателя к работам А. Л. Бема и М. С. Альтмана, в которых интерпретируются имена, в том числе и «птичьи» фамилии отдельных героев романа «Идиот» $(9,407)$. Но Альтман указывает именно на реальные прообразы Птицына, соотнося его фамилию с фамилиями двух известных в Петербурге «денежных дельцов и владельцев доходных домов» - Воронина и Утина [Альтман: 73-74] ${ }^{20}$. Возникает вопрос, насколько необходима такая информация в реальном комментарии. Думается, ее следует приводить, так 
как подобное пояснение в комментарии показывает связь художественного образа с явлениями реальности.

Вместе с тем в романе есть вымышленные фамилии, которые соотносятся не столько с реалиями, сколько с литературной традицией, и такие параллели также важны именно как элемент, проясняющий генезис созданных образов. Так, фамилии ростовщиков Киндер, Трепалов, Бискуп, не отраженные в реальном комментарии ПСС, вымышлены. Фамилией Трепалов далее в романе назван купец, у которого Тоцкий выпросил красные камелии $(8,128)$. М. С. Альтман полагал, что некоторые фамилии в романе «Идиот» созданы с ориентацией на гоголевский принцип рифмовки или удвоения («Ищенко и Фердыщенко - чем не гоголевские Карп и Поликарп?», «Соцкая и Тоцкий, Беспалова и Трепалов») [Альтман: 151]. Стоит обратить внимание на этимологию лексем, образующих фамилии Киндер и Бискуп и порождающих ассоциации со словами Kinder (нем. дети) и biskup (польск. епископ) ${ }^{21}$, значения которых противоречат роду деятельности ростовщиков. В данном случае при комментировании фактически соединяются разные типы комментария - словарный и интертекстуальный.

Еще одна фамилия, упоминаемая в романе («За Купферовы векселя не бойся...»-8, 251), комментария не получила, ее происхождение неясно. Однако она не является вымышленной, так как упоминается во «Всеобщей адресной книге СанктПетербурга...» за 1867-1868 гг. в разделе «Специальные занятия и ремесла»: по ул. Б. Мещанская, д. 20, кв. 4 жил дантист П. И. Купфер ${ }^{22}$. Большая Мещанская улица, угол Казанской площади, № 1/29, дом купца Б. Кохендёрфера (ныне Казанская ул., № 2/1) - один из адресов Достоевского в 1840 -е годы [Тихомиров, 2016: 41-43]. В романе «Идиот» фамилией Купфер наделен ростовщик, что становится своеобразным намеком на ее этимологию: нем. Kupfer - медь, медные деньги ${ }^{23}$.

В тексте романа встречаются высказывания героев, являющиеся аллюзиями на определенную реально-историческую систему идей и вместе с тем отражающие авторское восприятие проблемы. Такова реплика Коли Иволгина «У нас все обличают» $(8,113)$. В ПСС эта фраза не комментируется. В петрозаводском издании Полного собрания сочинений Достоевского указано, 
что «эпоха обличений в русской литературе и журналистике началась с наступлением гласности и реформ царствования Александра II» ${ }^{24}$. Действительно, так называемое «обличительное направление» в русской литературе стало постоянной темой критических публикаций в 1860-е годы, хотя точнее было бы возводить указанную идеологию к В. Г. Белинскому, который считал родоначальником «отрицательной» сатирической литературы Н. В. Гоголя. Взгляды Белинского, высказанные им, в частности, в статье «Несколько слов о поэме Гоголя» (1842), были оспорены в работе А. В. Дружинина «Критика гоголевского периода русской литературы и наши к ней отношения» (1856), появившейся в контексте полемического обсуждения «Очерков гоголевского периода русской литературы» (1855-1856) Н. Г. Чернышевского. Дружинин писал: «Гоголь не есть поэт отрицания, а между тем критика сороковых годов, сама вдавшись в одностороннее отрицательное направление, силилась видеть в Гоголе его полное воплощение» ${ }^{25}$. Из литературно-критических выступлений Достоевского следует, что он тоже связывал тему сатирического отрицания действительности с творчеством Гоголя. Во «Введении» к «Ряду статей о русской литературе» писатель назвал Гоголя «колоссальным демоном», который «смеялся всю жизнь и над собой и над нами, и мы все смеялись за ним, до того смеялись, что наконец стали плакать от нашего смеха. <...> явились поэты, прозаики, и всё обличительные... явились такие поэты и прозаики, которые никогда бы не явились на свет, если б не было обличительной литературы» $(18,59-60)$.

Мысль Коли Иволгина «У нас все обличают» сам Достоевский неоднократно проговаривал в журнальных публикациях 1860-х годов:

«Родилось у нас тогда какое-то усиленное самообвинение и самоуличение, а вместе с тем все наперерыв уличали и обличали друг друга...» («Ряд статей о русской литературе. Введение»18,58, см. также коммент. на с. 245-246, 271);

«Мы остановились на том, что повсеместно у нас раздались вопросы: кто виноват? Затем стали искать виноватых. Затем стали намекать, указывать, обличать» («Щекотливый вопрос. Статья со свистом, с превращениями и переодеваньями» $-20,32$ ); 
«Что может быть возмутительнее, когда какая-нибудь совершенно спокойная, сытая и вседовольная верхоглядка, чаще всего пошлейшая бездарность, думает выиграть на моде к прогрессу, обличает, свищет и выходит из себя за правду по заказу и по моде» («Необходимое литературное объяснение по поводу разных хлебных и нехлебных вопросов» - 20, 50-51);

«Когда вы сочиняли ваши обличительные вещи, вы и обличали не из негодования какого-нибудь и не из убеждения в чем-нибудь, а просто потому, что обличение модная, так сказать, струя» («Опять “Молодое перо”» - 20, 92).

Наконец, позднее, в черновиках «Дневника писателя» за 1876 г. Достоевский говорил о необходимости «плюсовых идеалов» в литературе (подробнее см.: [Тарасова, 2011: 245-247]). Таким образом, реплика Коли Иволгина становится своего рода идеологической отсылкой как к журнальной полемике 1840-1860-х гг., так и к взглядам самого Достоевского, нашедшим выражение в программных статьях «Времени» и «Эпохи» и получившим развитие в «Дневнике писателя». Нет сомнений, что к подобным местам в тексте - назовем их идеологемами (в данном случае это слово «обличают») - необходим реальный комментарий, который показывал бы исторический контекст идеологемы и ее место в художественной идеологии автора.

В комментарии, отсылающем читателя к авторской системе идеологических координат, нуждаются реплики генерала Епанчина «- Человек образованный, но погибший!» и «Искренно жаль! Погибшая женщина!» $(8,142,148)$. Первое суждение высказано в адрес князя Мышкина, во втором речь идет о Настасье Филипповне. Эти оценки принадлежат «умному и ловкому человеку», "хорошо знавшему свое место» $(8,14)$, и характеризуют его самого как представителя светского общества, в котором поступки князя Мышкина и тем более Настасьи Филипповны рассматриваются как нарушение приличий. Вместе с тем важно понять, что собою представляет определение «погибший» (не случайно объединившее Мышкина и Настасью Филипповну, если вспомнить трагический финал «Идиота») в культурно-историческом контексте и в авторском восприятии. «Погибший человек» - слова из редакционного предисловия к публикации перевода романа 
В. Гюго «Собор Парижской Богоматери» в журнале «Время» (1862), отражающие одну из важнейших идей Достоевского. По замечанию писателя, «основная мысль всего искусства девятнадцатого столетия», «мысль христианская и высоконравственная», есть «восстановление погибшего человека, задавленного несправедливо гнетом обстоятельств, застоя веков и общественных предрассудков. Эта мысль - оправдание униженных и всеми отринутых парий общества» $(20,28)$. Оправдание и восстановление погибшего человека - одна из ключевых проблем романа «Идиот», представленная именно в образах «Князя-Христа» и «падшей женщины». Определение «погибший человек» встречается в других произведениях Достоевского («Неточка Незванова», «Дядюшкин сон», «Униженные и оскорбленные», «Игрок», «Братья Карамазовы»; в варианте «погибший в пороках человек» в «Преступлении и наказании» $-6,255)$. Образ «погибшей женщины» отсылает читателя к теме грехопадения и восходит к евангельскому образу Марии Магдалины (см.: 9, 394-395), а в контексте литературной традиции - к «Фаусту» Гете и образу Гретхен (см.: [Тарасова, 2010]) и к пушкинским мотивам, ср. в «Пире во время чумы»: «Погибшего, но милого созданья...» ${ }^{26}$. Стоит отметить, что выражения «погибший человек» и «погибшая женщина» появляются позднее в характеристике героев романа Л. Н. Толстого «Анна Каренина»

В романе «Идиот» упоминается о том, что между Лизаветой Прокофьевной и Колей Иволгиным вышел спор «из-за “женского вопроса"» $(8,157)$. Необходимо отметить иронический контекст повествования - названные герои совпадают в ряде характеристик (эмоциональная открытость, прямолинейность оценок, детскость, несмотря на большую разницу в возрасте), а «жестоко» поссорились они дважды - по поводу «женского вопроса» и «второй раз из-за вопроса, в которое время года лучше ловить чижиков» $(8,157)$. Соединение этих двух несопоставимых тем создает комический эффект. И в то же время «женский вопрос» - тема, которая всерьез интересовала Достоевского и которая нуждается в пояснении. Формального словарного комментария недостаточно и в этом случае. Вопрос о положении женщины в обществе и равенстве ее 
в гражданских правах с мужчинами был связан с проблемой женской эмансипации. Началом борьбы за права женщин в Европе принято считать конец XVIII в., время Великой Французской революции и изменения иерархической структуры общества (см. подробнее: [Варламова: 21-25]). В России активное участие женщин в общественной жизни проявляется, начиная с эпохи петровских реформ и, позднее, правления Екатерины II, в XIX столетии - в эпоху реформаторской деятельности Александра II [Варламова: 25-29]. На этот же период - 1860-е годы - пришлось издание журналов братьев Достоевских «Время» и «Эпоха», где также появлялись публикации по «женскому вопросу», который рассматривался «прежде всего с точки зрения женского образования» [Варламова: 49]. Одним из ярких примеров публицистики Достоевского, затрагивающей «женский вопрос», явились, в частности, статьи «Образцы чистосердечия» ${ }^{28}$ и «Ответ "Русскому вестнику" ${ }^{29}$ (см. подробнее: 19, 91-104, 119-139, 292-295, 300-308). Во второй статье писатель отчетливо проговорил свое отношение к проблеме равноправия женщин, подчеркнув, что «вся эманципация сводится к христианскому человеколюбию, к просвещению себя во имя любви друг к другу, - любви, которой имеет право требовать себе и женщина» $(19,126)$. В романе «Идиот», как отмечено, прозвучал полемический отклик на роман Н. Г. Чернышевского «Что делать?» в его социологизированной трактовке «женского вопроса» (см.: 9, 392-393, 444, 445) ${ }^{30}$. Указанная проблематика сохраняет свое значение и в более поздний период издания «Гражданина» и в публицистике «Дневника писателя» (см.: [Буданова], [Фокин]).

В ПСС отсутствует комментарий к некоторым словесным деталям описания, касающимся темы нигилизма. Во-первых, это часть внутреннего монолога Лизаветы Прокофьевны:

«"Нигилистки растут, да и только!” - говорила она про себя поминутно. В последний год, и особенно в самое последнее время, эта грустная мысль стала всё более и более в ней укрепляться. “Во-первых, зачем они замуж не выходят?” - спрашивала она себя поминутно. "Чтобы мать мучить, - в этом они цель своей жизни видят, и это, конечно, так, потому что всё это новые идеи, 
всё это проклятый женский вопрос! Разве не вздумала было Аглая назад тому полгода обрезывать свои великолепные волосы? <...>”» $(8,271)$.

Попытка сестер Епанчиных остричь волосы, действительно, могла восприниматься как проявление «нигилизма». В этом отношении уместно вспомнить высказывание А. Я. Панаевой, прозвучавшее в связи с откликом на антинигилистический роман И. С. Тургенева «Отцы и дети»: «Стриженые волосы, отсутствие кринолина или барашковая шапка на голове женщины производили сенсацию в публике и приводили многих в ужас. Такой женщине не было прохода от презрительных взглядов и насмешек, сопровождаемых кличкой “нигилистка”»"31.

Во-вторых, это авторское описание, содержащее следующую проницательную критическую оценку так называемых нигилистов:

«Ограниченному “обыкновенному” человеку нет, например, ничего легче, как вообразить себя человеком необыкновенным и оригинальным и усладиться тем без всяких колебаний. Стоило некоторым из наших барышень остричь себе волосы, надеть синие очки и наименоваться нигилистками, чтобы тотчас же убедиться, что, надев очки, они немедленно стали иметь свои собственные “убеждения” ( $(8,384)$.

Эта характеристика внешнего вида нигилисток совпадает с замечанием А. И. Герцена в «Былом и думах» (см. раздел «Другие редакции»): «...волосы острижены, блеск глаз ослаблен синими очками, чтобы не мрачить единственный свет разума. Другие времена - другие нравы, различия полов почти забыты пред лицом науки» ${ }^{32}$. Н. Н. Страхов на ту же тему высказывался критически: «Пусть читатель переберет потом все хорошо знакомые ему формы нигилизма. Молодая девушка обрезывает свою великолепную косу и надевает синие очки. Со стороны безобразно, а между тем она очень довольна собою, как будто надела наряд красивее того, который прежде носила $»^{33}$. Отрицательное отношение к внешнему облику нигилистов было распространенным; стереотипность восприятия иной раз приводила к казусам. Д. С. Мережковский упомянул такой случай: «В 1872 году, в Петербурге одну молодую девушку, 
дочь действительного статского советника, остригшую себе волосы после тифа и по слабости глаз носившую очки, городовые схватили на улице и отвели в часть как нигилистку» ${ }^{34}$. По мысли современного исследователя (фактически совпадающей с выводом Достоевского в романе «Идиот»), «синие очки так запомнились современникам потому, что в них-то и было дело, под очками был не кризис ценностей, а стремление его имитировать, и далее этих синих очков нигилизм не шел» [Шоломова: 130].

Слова Ипполита «думал только четверть часа говорить и всех, всех убедить» $(8,247$, ср.: 244) получают комментарий в ПСС $(9,445)$, который следует дополнить. Ю. М. Лотман связал мотив предсмертного желания Ипполита «держать речь к народу» с «моментом смерти Белинского, так поразившим всё его окружение» (см.: [Лотман, 1996: 158]): в воспоминаниях И. С. Тургенева приведены выдержки из письма А. П. Тютчевой, в котором указывалось, что Белинский перед смертью «говорил два часа не переставая, как будто к русскому народу» ${ }^{35}$ (ср. строки из поэмы Н. А. Некрасова «Несчастные» (1856): «В день смерти с ложа он воспрянул. <...> Ему мерещился народ / И звон московских колоколен; / Восторгом взор его сиял, / На площади, среди народа, / Ему казалось, он стоял / И говорил...») ${ }^{36}$. Достоевскому могло быть известно это расхожее мнение современников о смерти Белинского. Вместе с тем в других текстах писателя звучат сходные оценки в адрес Н. Г. Чернышевского и Н. А. Добролюбова: «А наш Чернышевский говаривал, что стоит ему четверть часа с народом поговорить и он тотчас же убедит его обратиться в социализм» (из письма к М. Н. Каткову от 25 апреля 1866 г. - 282, 154); «...так думали Чернышевский и Добролюбов: четверть часа поговорить в окошко с народом, и он пойдет за вами...» (черновые рукописи романа «Подросток» - 16, 170). В статье Чернышевского «Полемические красоты» (1861) есть стилистически похожее высказывание: «Вот горячились вы, горячились и никак не могли добиться, чего мы хотим, что любим; теперь же, только четверть часа побеседовали мы с вами хладнокровно, и открылось вам все: любим мы родину свою, а хотим - добра ей, - только и всего» ${ }^{37}$. Кроме того, Достоевский использовал 
сходное выражение, рисуя собирательный образ «теоретиков», «социалистов» и «современных позитивистов»: «Мы положительно уверены, что самые умные из них (теоретиков. - H. T.) думают, что при случае стоит только десять минут поговорить с народом и он все поймет; тогда как народ, может быть, и слушать-то их не станет, об чем бы они ни говорили ему» (Объявление о подписке на журнал «Время» на 1863 г. - 20, 208); «...дайте мне четверть часа только поговорить без цензуры с народом, и он тотчас за мной пойдет» (черновые рукописи романа «Бесы» - 11, 78; 12, 336).

Не получили необходимого комментария в ПСС строки:

«Мой либерал дошел до того, что отрицает самую Россию Эту ненависть к России, еще не так давно, иные либералы наши принимали чуть не за истинную любовь к отечеству и хвалились тем, что видят лучше других, в чем она должна состоять; но теперь уже стали откровеннее и даже слова "любовь к отечеству” стали стыдиться, даже понятие изгнали и устранили, как вредное и ничтожное» $(8,277)$.

Этот пассаж содержит идеологемы, значимые для текстов Достоевского, как художественных, так и публицистических. Тему ненависти к России затрагивали многие авторы, начиная с 1820-х годов ${ }^{38}$. Наибольшую известность получили высказывания П. Я. Чаадаева, который в статье «Философическое письмо» (1836) дал уничижительные оценки России, противопоставив ее западной цивилизации как более развитому устройству жизни и тем самым предвосхитив будущие дискуссии славянофилов и западников. Откликаясь на строки из письма Достоевского к А. Н. Майкову от 16 (28) августа 1867 г. $\left(28_{2}, 210\right)$, Ф. И. Тютчев в письме А. Ф. Аксаковой от 20 сентября 1867 г. сообщал:

«Посылаю твоему мужу, отнюдь, разумеется, не с целью предания гласности, а для его личного ознакомления, отрывок из письма к Майкову Достоевского, в котором он рассказывает о своей встрече с Тургеневым в Бадене. Аксаков мог бы развить это в статью, которая была бы сейчас как нельзя более кстати. - В ней следовало бы рассмотреть современное явление, приобретающее все более патологический характер. Речь идет о русофобии некоторых русских - причем весьма почитаемых... Прежде они говорили нам, и говорили совершенно 
искренно, что Россия их отвращает отсутствием прав, свободы слова и т. д. и т. д., а Европа внушает им нежную любовь именно наличием там всего этого... Что же мы видим теперь? По мере того как Россия, добиваясь некоторых послаблений, все более самоутверждается, отвращение к ней этих господ только растет. Ибо, судя по всему, прежние порядки никогда не вызывали у них столь лютой ненависти, как современные направления национальной мысли... И напротив, сколько бы ни попирали в Европе право, нравственность, саму цивилизацию, это, как мы видим, ничуть не уменьшает их расположения к Западу. <..> Словом, в означенном мною явлении принципы, как таковые, никак не замешаны, тут нет ничего, кроме инстинктов, и вот природу-то этих инстинктов и нужно бы проанализировать» ${ }^{39}$.

Позднее Достоевский отчасти повторил в «Дневнике писателя» за 1877 г. мысль, высказанную в романе «Идиот»:

«Эмигрировали из России (я удерживаю это слово) двадцать лет назад наиболее помещики <...> были всякие, но, в огромном большинстве, если не все, - более или менее ненавидящие Россию, иные нравственно, вследствие убеждения, “что в России таким порядочным и умным, как они, людям нечего делать”, другие уже просто ненавидя ее безо всяких убеждений, так сказать, натурально, физически: за климат, за поля, за леса, за порядки, за освобожденного мужика, за русскую историю, одним словом, за всё, за всё ненавидя» $(25,137)$.

Что касается слов «любовь к отечеству», прозвучавших в «Идиоте», то тема, ими обозначенная, восходит к публицистике XVIII в. (см., например, статью А. Н. Радищева «Беседа о том, что есть сын отечества», 1789) и рассматривается в работе Н. М. Карамзина «О любви к отечеству и народной гордости» (1802). Последняя статья могла быть известна Достоевскому, «возросшему на Карамзине» (собственное признание в письме к Н. Н. Страхову от 2 (14) декабря 1870 г. - ПСС 29, 153).

Отдельная проблема - комментирование библейских цитат и аллюзий. Достаточно долгое время, по причине редуцированного внимания к библейской проблематике, этот вид интертекста не получал развернутого комментария или же комментировался с неточностями. Рассмотрим некоторые примеры. Так, Лебедев в романе «Идиот», разговаривая с князем 
Мышкиным, сообщает о «вскидчивом» настроении Настасьи Филипповны и добавляет: «Апокалипсисом стал отчитывать» $(8,167)$. В реальном комментарии ПСС к этому месту после краткой справки об Апокалипсисе как части Нового Завета сказано, что «Достоевский не раз обращался к апокалипсическим образам», «начиная с “Зимних заметок о летних впечатлениях"» $(9,439)$, опубликованных в 1863 г. Это неточное утверждение. Еще в «Двойнике» (1846) званый обед у Берендеева сравнивается с «чем-то вавилонским в отношении блеска, роскоши иприличия» (ПСС-2, 1, 150), и аллюзия на чрезмерную роскошь и блистательность восходит к Откровению Иоанна Богослова, в котором описывается гибель «великого Вавилона» как воплощения грехов (Откр. 18:1-24).

Необходимо также уточнить особенности включения в текст романа библейского мотива побиения камнями, ср. слова князя Мышкина о Настасье Филипповне: «О, не позорьте ее, не бросайте камня» $(8,361$; см. также: $9,395,434)$. Этот же мотив возникает в сюжете о Мари:

«Вдруг в это время нас подглядели дети, целая толпа; я потом узнал, что они давно за мной подсматривали. Они начали свистать, хлопать в ладошки и смеяться, а Мари бросилась бежать. Я хотел было говорить, но они в меня стали камнями кидать» $(8,60)$.

В Библии указанный мотив выражен вариантно - в словах Христа о блуднице, переданных в Евангелии от Иоанна: «А как настоятельно стали спрашивать Его: то восклонясь, сказал им: кто из вас без греха, пусть первый бросит на нее камень» (Ин. 8:7); в эпизоде, в котором иудеи собираются побить Христа камнями: «Иудеи сказали Ему в ответ: не за доброе дело хотим побить Тебя камнями, но за богохульство, $и$ за то, что Ты, будучи человек, делаешь Себя Богом» (Ин. 10:33); в строках из Послания св. апостола Павла к Евреям о пророках, которые «верою побеждали царства, творили правду» и «камнями побиваемы были» (Евр. 11:33-37) ${ }^{40}$. Учитывая совокупность приведенных значений, следует отметить, что в романе «Идиот» сохранено вариантное содержание мотива, который становится характеристикой не только образа Настасьи 
Филипповны, но и князя Мышкина в контексте христианских представлений о грехе и вере.

Реплика Лебедева, обращенная к князю Мышкину: «...если и могу служить вам, то как раб и наемщик, не иначе...» $(8,405),-$ не получила комментария в ПСС. Слова «раб» и «наемщик» (здесь: «наемник») восходят к библейскому тексту, где употребляются как в своем историческом значении - «рабочая сила» (ср.: «...и будет это в продолжение субботы земли всем вам в пищу, тебе и рабу твоему, и рабе твоей, и наемнику твоему, и поселенцу твоему, поселившемуся у тебя...» (Лев. 25:6); «Не обижай раба, трудящегося усердно, ни наемника, преданного тебе душею...» (Сир. 7:22, см.: Втор. 24:14) и др.), так и в символическом смысле, при обозначении духовного рабства и греха: «Пришедши же в себя, сказал: сколько наемников у отца моего довольствуются хлебом с избытком, а я мру с голоду! Встану, пойду к отцу моему, и скажу ему: родитель! я согрешил против неба и пред тобою, и уже недостоин называться сыном твоим: прими меня в число наемников твоих» (Лк. 15:17-19); «Или вы не знаете, что кому вы отдаете себя в рабы для послушания, тому вы и рабы, смотря потому, кому послушны, или греху к смерти, или послушанию к праведности?» (Рим. 6:16) ${ }^{41}$. К Лебедеву, который постоянно подчеркивает свое ничтожество, кается, словно признавая свои грехи, и в то же время продолжает интриговать и лицедействовать, применимы оба толкования.

Библейские интертексты, будучи включенными в текст романа, могут переосмысливаться, наделяться новыми значениями, взаимодействовать с другими (например, литературными) интертекстами и особенностями поэтики произведения, отражая направление авторской мысли. Примером служит фраза Лебедева «Ибо нищ и наг, и атом в коловращении людей» $(8,168)$. В ПСС $(9,439)$ комментируется только первая часть предложения с указанием на неточную цитату из Апокалипсиса: «Ибо ты говоришь: я богат, разбогател, и ни в чем не имею нужды; а не знаешь, что ты жалок, и беден, и нищ, и слеп, и наг» (Откр. 3:17) ${ }^{42}$. Но высказывание Лебедева содержит не только отсылку к библейскому тексту. В речи героя оно является очередной формулой самоуничижения, 
чему служит и дальнейшее сравнение с атомом. Слово «атом» Достоевский использовал в значении «мизерный, ничтожный» (ср. в «Дневнике писателя» за 1876 г.: «что он вовсе не атом и не ничто перед ними» - 22, 6). Едва ли следует оставлять без комментария слово «коловращение», так как здесь необходимо не только пояснить прямое словарное его значение («круговорот»), но и указать на соответствующий литературный контекст. Метафора «коловращенье людей» встречается во втором томе «Мертвых душ» (1835-1841, опубл. в 1842 г.; т. 2 - в 1855 г.) Н. В. Гоголя: «...видеть свет, коловращенье людей - кто что ни говори, есть как бы живая книга, вторая наука» ${ }^{43}$.

Не получила комментария в ПСС еще одна отсылка к библейским и литературным источникам, содержащаяся в словах генерала Иволгина, обращенных к Ипполиту: «...а ты только завистливый червь, перерванный надвое, с кашлем... и умирающий от злобы и от неверия...» $(8,395)$. Сравнение «человек - червь» имеет библейские (ветхозаветные) источники: «Тем менее человек, который есть червь...» (Иов. 25:6); «Я же червь, а не человек, поношение у людей и презрение в народе» (Пс. 21:7, см. также: Ис. 41:14). Метафора получила широкое распространение в русской литературе и встречается, к примеру, в текстах Г. Р. Державина («Я царь - я раб я червь — я Бог!» — ода «Бог», 1784), Н. М. Карамзина («И в темницу преисподню / Засадите вы его. / Пусть гниет там понемногу, / И умрет, как бедный червь!» - «Граф Гваринос», 1789), А. С. Пушкина («Несносен мне твой ропот дерзкий, / Ты червь земли, не сын небес...» - «Поэт и толпа», 1829), М. Ю. Лермонтова («...не жди пощады; / Как червь, к душе твоей / Я прилеплюсь, и каждый миг отрады / Несносен будет ей...» - «Настанет день - и миром осужденный», 1831, опубл. в 1859), Н. В. Гоголя («незначащий червь мира сего» - слова Чичикова о себе в «Мертвых душах»; ср. в Библии: «князь мира сего», о сатане - Ин. 12:31), Л. Н. Толстого («...и я, ничтожный червяк, уже оскверненный всеми мелкими, бедными людскими страстями» — «Юность», 1855-1856, гл. ХХХІІ), И. С. Тургенева (умирающий Базаров о себе: «червяк полураздавленный, а еще топорщится» - «Отцы и дети», 1860-1861, опубл. в 1862) и др. авторов ${ }^{44}$. Указанная метафора также встречается в «Фаусте» И. В. Гете ${ }^{45}$. 
Остались не замеченными исследователями и не получили комментария две отсылки к Библии в подготовительных материалах к роману «Идиот». Ветхозаветная цитата звучит в строках первоначальной редакции романа: «Заклады ложек. Тесное время. Идиот не едет» $(9,207)$. Тесное время - время скорби, печали. Ср.: «А вы оставили Меня и стали служить другим богам; за то Я не буду уже спасать вас: пойдите, взывайте к богам, которых вы избрали, пусть они спасают вас в тесное для вас время» (Суд. 10:14, ср. Притч. 1:25-27); «И в тесное для себя время он продолжал беззаконно поступать пред Господом...» (2 Пар. 28:22); «И Ты отдал их в руки врагов их, которые теснили их. Но когда, в тесное для них время, они взывали к Тебе, Ты выслушивал их с небес и, по великому милосердию Твоему, давал им спасителей, и они спасали их от рук врагов их» (Неем. 9:27); «Посему будут прославлять Тебя народы сильные; города страшных племен будут бояться Тебя, ибо Ты был убежищем бедного, убежищем нищего в тесное для него время, защитою от бури, тенью от зноя; ибо гневное дыхание тиранов было подобно буре против стены» (Ис. 25:3-4, см. также: Ис. 33:2). Во втором случае это аллюзия на библейский текст: «Но Ганя гораздо серьезнее, чем в первых 2-х частях. Не проговаривается. Молчит. Таит» $(9,230)$. Ср.: «Кто ходит переносчиком, тот открывает тайну; но верный человек таит дело» (Притч. 11:13, см. также: Иов. 20:12-14).

Среди собственно литературных интертекстов следует выделить, во-первых, автореминисценции Достоевского. Так, например, не комментируемые в ПСС слова Лебедева о пропавшем бумажнике с деньгами: «...а знаете, князь, очевидно, что у меня где-нибудь в садике, под камушком, пролежали в первую-то ночь пропажи-с; как вы думаете?» $(8,409)$ - это явная отсылка к мотиву, прежде возникшему в романе «Преступление и наказание», где Раскольников прячет под камень взятые у процентщицы деньги и вещи.

Автореминисценцией к публицистическим статьям Достоевского 1860-х годов, в которых обосновывается почвенническое учение, стала фраза «Кто почвы под собой не имеет, тот и Бога не имеет» $(8,452)$. По замечанию В. В. Виноградова, в 1840-1850-е гг. слово «почва» «сближается с французским terrain», и под влиянием переносного словоупотребления складывается «новая фразеология» - «в слове почва, отчасти 
на основе его старого значения - “основание, фундамент”, отчасти на основе семантических толчков, идущих от французского языка, развивается фразеологически связанное переносное значение - "опора, основа, то, на чем можно утвердиться"» [Виноградов: 529]. В таком значении это слово использовали многие авторы, в том числе Достоевский [Виноградов: 530], для которого оно ассоциировалось с национальной средой, народными основами жизни и христианской верой. Мысль, высказанная в «Идиоте», перефразируется в романе «Бесы» (слова Шатова): «А у кого нет народа, у того нет и Бога!» $(10,34)$.

Еще одна автореминисценция отражает сквозную тему, звучащую в творчестве Достоевского: «...действительно ли весь этот верхний слой русских людей уж никуда не годится, отжил свое время, иссяк исконною жизнью и только способен умереть, но всё еще в мелкой, завистливой борьбе с людьми... будущими...» $(8,456-457)$. Выражением «верхний слой русских людей» обозначено дворянское сословие. Ср. с лексически близкими вариантами в «Дневнике Писателя»: «самим верхним сословием» $(22,31)$, «верхние слои культурных людей в России» $(22,110)$, «верхним слоем культурных людей», «между простонародьем и верхним культурным слоем» (Там же), «верхний культурный слой русский» $(23,46)$, «верхнее общество» $(23,160)$, «народ невольно признает верхних людей» $(26,31)$, «нашего верхнего над народом стоящего общества» $(26,143)$. Критикуя дворянское общество в духе почвеннических идей, Достоевский подверг тему многостороннему анализу. В «Подростке» говорится о дворянстве как символе «высшей идеи», под которой понимается «идея чести и просвещения». В определении героя романа, Версилова, дворянство - это не столько сословие, сколько «собрание лучших людей, в смысле буквальном и истинном, а не в прежнем смысле привилегированной касты» $(13,177-178)$. Образ «лучших людей» указывает на несоциальное, духовное содержание этой темы. В «Дневнике Писателя» тема «верхнего слоя русских людей» представлена, в частности, в «споре» Достоевского с героем романа «Анна Каренина» Левиным, который назван «московским баричем средне-высшего круга» $(25,205)$. Роман «Идиот» во многом 
предвосхищает развитие указанной проблематики: слова князя Мышкина о людях «будущих» близки к более поздним рассуждениям Достоевского и его героев о «лучших людях» (см. также: [Галаган]).

Слова князя Мышкина: «...чтоб утолить жажду духовную...» $(8,451)$, «...из боли духовной, из жажды духовной, из тоски по высшему делу...» $(8,452)$ - отсылают читателя к стихотворению А. С. Пушкина «Пророк» (1826). В данном случае важно отметить, что цитата («Духовной жаждою томим...»), которая в тексте-источнике обозначает движение лирического героя к прозрению и обретению Бога, в романе «Идиот» включена в контекст рассуждений о "русских атеистах» темы, к которой Достоевский обратился и в неосуществленном замысле «Атеизм», возникшем параллельно работе над романом «Идиот». О «тоске по идеалу», «жажде великих идей», «дворянской тоске» позднее говорят Версилов и Аркадий Долгорукий в романе «Подросток» (см.: 13, 373-374, 376-380; $16,45,78,282,340-341,367-368)$.

Очевидной отсылкой к литературной традиции являются слова Евгения Павловича о Петербурге как «почти фантастическом» городе $(8,482)$, которые также не получили комментария в ПСС. В данном случае уместно указать на параллели с предшественниками Достоевского в развитии петербургской темы - А. С. Пушкиным («Пиковая дама», «Медный всадник») и Н. В. Гоголем («Невский проспект» и «петербургские повести» в целом), создавшими образ призрачного, фантастического, демонического города-миража. Достоевский обращается к этой теме в раннем творчестве («Двойник», «Белые ночи», «Петербургские сновидения в стихах и прозе»), но и в более позднее время, в романе «Подросток», звучит ее отголосок - в упоминании названных пушкинских текстов:

«...замечу, что считаю петербургское утро, казалось бы самое прозаическое на всем земном шаре, - чуть ли не самым фантастическим в мире. Это мое личное воззрение или, лучше сказать, впечатление, но я за него стою. В такое петербургское утро, гнилое, сырое и туманное, дикая мечта какого-нибудь пушкинского Германна из “Пиковой дамы” (колоссальное лицо, необычайный, совершенно петербургский тип - тип из петербургского периода!), мне кажется, должна еще более укрепиться. Мне сто 
раз, среди этого тумана, задавалась странная, но навязчивая греза: “А что, как разлетится этот туман и уйдет кверху, не уйдет ли с ним вместе и весь этот гнилой, склизлый город, подымется с туманом и исчезнет как дым, и останется прежнее финское болото, а посреди его, пожалуй, для красы, бронзовый всадник на жарко дышащем, загнанном коне?"» $(13,113)$.

Анализ материала свидетельствует о том, что реальный комментарий многослоен и не ограничивается пояснением так называемых «исторических реалий». Происходит это потому, что «реалии» видоизменяются, будучи воспринятыми авторским сознанием и становясь частью художественного текста, а иногда и более широкого историко-литературного контекста. Кроме того, в реальном комментарии действуют разные типы комментирования, от идиолектного до интертекстуального, и чаще всего не по отдельности друг от друга, а в соединении, когда к этому ведет комментируемый текст. Такой ситуации, кроме того, способствует сама модель построчного комментария, предполагающая движение исследователя вслед за автором и авторской логикой.

\section{Примечания}

1 Достоевский Ф. М. Полн. собр. соч.: в 30 т. Л.: Наука, 1972-1990. Далее ПСС; ссылки на это издание приводятся в тексте статьи с указанием тома и страницы в круглых скобках. При необходимости приводятся также ссылки на новое продолжающееся издание - ПСС-2: Достоевский Ф. М. Полн. собр. соч.: в 35 т. Л.: Наука, 2013-2016. Т. 1-6.

2 См. также: [Лихачев: 528].

3 О проблемах комментирования см. также: [Лотман, 1995: 472-474], [Достоевский: Дополнения к комментарию], [Тихомиров, 2006: 2634, 39-40], [Тихомиров, 2008], [Исупов], [Смирнов], [Тименчик] и др.

4 Глинкина Л. А. Иллюстрированный толковый словарь забытых и трудных слов русского языка. М.: Мир энциклопедий Аванта+, 2008. С. 334.

5 Гоголь Н. В. Полн. собр. соч.: в 14 т. М.: Изд-во АН СССР, 1937-1952. T. 3. C. 156.

6 Черных П. Я. Историко-этимологический словарь современного русского языка: в 2 т. М.: Рус. яз., 2001. Т. 1. С. 162.

7 Глинкина Л. А. Иллюстрированный толковый словарь забытых и трудных слов русского языка. С. 69.

8 Мокиенко В. М., Никитина Т. Г. Большой словарь русских народных сравнений. М.: ОЛМА Медиа Групп, 2008. С. 625.

9 Словарь современного русского литературного языка: в 17 т. М.; Л.: Изд-во АН СССР, 1948-1965. Т. 13. Стб. 1414. 
10 См. также: Достоевский Ф. М. Полн. собр. соч.: канонические тексты / под ред. В. Н. Захарова. Петрозаводск: Изд-во ПетрГУ, 1995-2015. Т. 8. С. 802.

11 См.: Национальный корпус русского языка. [Электронный ресурс]. URL: http://www.ruscorpora.ru/search-main.html

12 Михельсон М. И. Русская мысль и речь. Свое и чужое: Опыт русской фразеологии: сб. образных слов и иносказаний: в 2 т. М.: Терpa - Terra, 1994. Т. 1. С. 750.

13 См.: Достоевский Ф. М. Полн. собр. соч.: канонические тексты. Т. 8. C. 819.

14 Napoléon, par Alexandre Dumas. Paris: Delloye, 1840. P. 236.

15 Толковый словарь русского языка с включением сведений о происхождении слов / РАН. Ин-т рус. яз. им. В. В. Виноградова; отв. ред. Н. Ю. Шведова. М.: Издательский центр «Азбуковник», 2011. С. 237.

16 Сказания русского народа, собранные И. Сахаровым: в 2 т. 3-е изд. СПб.: Тип. Сахарова, 1841. Т. 1. С. 75.

17 Кунсткамера // Российский гуманитарный энциклопедический словарь: в 3 т. М.: Гуманит. изд. центр ВЛАДОС, 2002. Т. 2. С. 308-309. См. также: [The origins of museums...], [Куклинова, 1997], [Куклинова, 2001], [Юренева], [Mauriès].

18 Словарь личных имен у Достоевского / сост. А. Л. Бемом, С. В. Завадским, Р. В. Плетневым и Д. И. Чижевским; под общ. ред. А. Л. Бема. С. 338.

19 Достоевский Ф. М. Полн. собр. соч.: канонические тексты. Т. 8. С. 739.

20 О зоолексемах в фамилиях героев Достоевского см. также: [Владимирцев]; напр., о смысле «оксюморона-оппозиции» «Лев Мышкин» [Владимирцев: 304-306].

21 Достоевский Ф. М. Полн. собр. соч.: канонические тексты. Т. 8. С. 757.

22 Всеобщая адресная книга Санкт-Петербурга, с Васильевским островом, Петербургскою и Выборгскою сторонами и Охтою. СПб.: Изд. Гоппе и Корнфельда, 1867-1868. Отд. IV. С. 58.

23 Достоевский Ф. М. Полн. собр. соч.: канонические тексты. Т. 8. С. 792.

24 Там же. С. 757.

25 Дружинин А. В. Критика гоголевского периода русской литературы и наши к ней отношения // Дружинин А. В. Литературная критика / сост., подгот. текста и вступ. ст. Н. Н. Скатова, примеч. В. А. Котельникова. М.: Сов. Россия, 1983. С. 168.

26 Достоевский Ф. М. Полн. собр. соч.: канонические тексты. Т. 8. С. 762.

27 Толстой Л. Н. Полн. собр. соч.: в 90 т. М.: Гослитиздат, 1928-1959. Т. 18. C. $30,219$.

28 Время. 1861. № 3. С. 54-70.

29 Там же. № 5. С. 15-39.

30 См. также: 7, 371-372; Достоевская А. Г. Воспоминания / вступ. ст., подгот. текста и примеч. С. В. Белова и В. А. Туниманова. М.: Худож. лит., 1987. С. 173-174. (Сер. лит. мемуаров), [Касаткина, 1996: 218-226].

31 Панаева А. Я. (Головачева) Воспоминания. М.: Правда, 1986. С. 320. См. также: [Вознесенская]. 
32 Герцен А. И. Собр. соч.: в 30 т. М.: Изд-во АН СССР; Наука, 1954-1966. T. 1. C. 558.

33 Страхов Н. Н. Преступление и наказание. Роман в шести частях с эпилогом. Ф. М. Достоевского. Издание исправленное. Два тома. Петербург. 1867 // Отечественные записки. 1867. № 3, кн. 2. С. 331.

34 Мережковский Д. С. «Больная Россия». Избранное. Л.: Изд-во ЛГУ, 1991. С. 185.

35 Тургенев И. С. Полн. собр. соч. и писем: в 30 т. Сочинения: в 12 т. 2-е изд., испр. и доп. М.: Наука, 1978-2018. Т. 11. С. 52. Ср.: «О смерти его мне рассказывали, что он был в забытьи, бредил, говорил речи народу...» (Кавелин К. Д. Воспоминания о В. Г. Белинском // В. Г. Белинский в воспоминаниях современников. М.: Худож. лит., 1977. С. 180-181).

36 Некрасов Н. А. Полн. собр. соч. и писем: в 15 т. Л.; СПб.: Наука, 1981-2000. Т. 4. С. 49.

37 Чернышевский Н. Г. Полн. собр. соч.: в 16 т. М.: Гослитиздат, 1939-1953. T. 7. C. 756.

38 См. подробнее: Достоевский Ф. М. Полн. собр. соч.: канонические тексты. Т. 8. С. 796.

39 Тютчев Ф. И. Полн. собр. соч. и письма: в 6 т. М.: ИЦ «Классика», 2004. T. 6. C. 271, 514-515.

40 См.: Евангелие Достоевского: [Личный экземпляр Нового Завета 1823 года издания, подаренный Ф. М. Достоевскому в Тобольске в январе 1850 года]: [в 3 т.]. Тобольск: Общественный благотворительный фонд «Возрождение Тобольска», 2017. Т. 1: Новый Завет. Факсимиле издания 1823 года. Описание маргиналий и владельческих помет. Сибирская тетрадь. Факсимиле. С. 238, 247, 576.

41 См.: Евангелие Достоевского. Т. 1. С. 184, 412.

42 Ст. 14-17 отчеркнуты карандашом; начало 14 и окончание 17 стихов отграничены карандашом знаками «|». См.: Евангелие Достоевского. T. 1. C. 587; T. 2. C. $720-721$.

43 Гоголь Н. В. Полн. собр. соч.: в 14 т. М.; Л.: Изд-во АН СССР, 1951. Т. 7. С. 54, см. там же с. $61,92$.

44 См. подробнее: Кожевникова Н. А., Петрова 3. Ю. Материалы к словарю метафор и сравнений русской литературы XIX-XX веков / отв. ред. Л. Л. Шестакова. М.: Языки славянских культур, 2010. Вып. 2: Звери, насекомые, рыбы, змеи. С. 341-343.

45 См.: Достоевский Ф. М. Полн. собр. соч.: канонические тексты. Т. 8. C. 814.

\section{Список литературы}

1. Алёкин В. Н. Уточнения и дополнения к комментариям. [Электронный pecypc]. - URL: http://aljokin-1957.narod.ru/fan32.html (07.03.2019).

2. Альтман М. С. Достоевский: По вехам имен. - Саратов: Изд-во Саратовск. ун-та, 1975. - 280 с. 
3. Богданов К. А. Игра в жмурки: сюжет, контекст, метафора // Богданов К. А. Повседневность и мифология: исследования по семиотике фольклорной действительности. - СПб.: Азбука, 2015. - С. 104-171.

4. Буданова Н. Ф. Неизвестные статьи Достоевского по женскому вопросу: (Опыт атрибуции) // Достоевский. Материалы и исследования. - Л.: Наука, 1976. - Т. 2. - С. 236-244.

5. Варламова Д. В. Женский вопрос в журналах М. М. и Ф. М. Достоевских «Время» и «Эпоха»: дис. ... канд. филол. наук. - М., 2017. - 158 с.

6. Виноградов В. В. История слов: ок. 1500 слов и выражений и более 5000 слов, с ними связ. / РАН. Отд-е лит. и яз. Науч. совет «Рус. яз.». Ин-т рус. яз. им. В. В. Виноградова. - М.: ИРЯ, 1999. - 1138 с.

7. Владимирцев В. П. Поэтический бестиарий // Владимирцев В. П. Достоевский народный. - Иркутск: Изд-во Иркут. гос. ун-та, 2007. C. $300-315$.

8. Вознесенская А. П. Образ женщины-нигилистки как отражение смены ценностной парадигмы в культуре России XIX в. // Общество. Среда. Развитие. - 2012. — № 2. - С. 153-156.

9. Галаган Г. Я. Проблема «лучших людей» в наследии Ф. М. Достоевского (1873-1876) // Достоевский. Материалы и исследования. - СПб.: Дмитрий Буланин, 1996. - Т. 12. - С. 99-107.

10. Гаспаров М. Л. Ю. М. Лотман и проблемы комментирования // Новое литературное обозрение. - 2004. - № 66. - С. 70-74.

11. Дорофеева К. В. Житие преподобного Авраамия Галичского // Вестник церковной истории. - 2011. - № 1/2 (21/22). - С. 5-55.

12. Достоевский: дополнения к комментарию / Институт мировой литературы им. А. М. Горького РАН, Комиссия по изучению творчества Ф. М. Достоевского; под ред. Т. А. Касаткиной. - М.: Наука, 2005. - 694 с.

13. Захаров В. Н. Текстология как технология // Захаров В. Н. Проблемы исторической поэтики: этнологические аспекты. - М.: Индрик, 2012. - C. 205-221.

14. Захаров В. Н. «Бесы»: два романа, как издавать // Имя автора - Достоевский: очерк творчества. - М.: Индрик, 2013. - С. 317-352.

15. Исупов К. Г. Вненаходимость комментатора // Вопросы литературы. 2008. - № 2. - С. 6-19.

16. Казакова Т. А. Переводческий комментарий: структура и функции // Университетское переводоведение: материалы IV Межд. науч. конф. по переводоведению «Федоровские чтения» 24-26 октября 2002 г. СПб.: Филол. фак-т С.-Петерб. гос. ун-та, 2003. - Вып. 4. - С. 169-178.

17. Касаткина Т. А. Характерология Достоевского. Типология эмоционально-ценностных ориентаций. - М.: Наследие, 1996. - 336 с.

18. Касаткина Т. А. Проблемы реального комментария // Новый мир. 2018. — № 7. - С. 181-198.

19. Коробейникова Н. Н. Онтология комментария и его роль в понимании иноязычного художественного текста: автореф. дис. ... канд. филол. наук. - Барнаул, 2006. — 22 с. 
20. Крапивин Г. Н. К чему приложил руку игумен Пафнутий? // Русская литература. - 2014. - № 4. - С. 145-151.

21. Куклинова И. А. Кабинеты во Франции в XVI-XVII веках // Музей в современной культуре: сб. науч. тр. - СПб.: С.-Петерб. гос. академия культуры, 1997. - Т. 147. - С. 24-38.

22. Куклинова И. А. Музеи Франции XIV-XIX веков. - СПб.: СПбГУКИ, 2001. - Ч. 1. - 148 c.

23. Лихачев Д. С., при участии А. А. Алексеева и А. Г. Боброва. Текстология на материале русской литературы X-XVII веков. - СПб.: Алетейя, 2001. - $758 \mathrm{c}$.

24. Лотман Ю. М. Пушкин. - СПб.: Искусство-СПб., 1995. - 845 с.

25. Лотман Ю. М. Символ в системе культуры // Лотман Ю. М. Внутри мыслящих миров. Человек - текст - семиосфера - история. - М.: Языки русской культуры, 1996. - С. 146-160.

26. Манн Ю. Н. В. Гоголь: академический комментарий в поисках жанра // Проблемы текстологии и эдиционной практики. Опыт французских и российских исследователей. - М.: ОГИ, 2003. - С. 103-111.

27. Монологи о комментарии: Л. Г. Степанова // Текст и комментарий: круглый стол к 75-летию Вячеслава Всеволодовича Иванова / науч. совет РАН «История мировой культуры», МГУ им. М. В. Ломоносова; [сост. Д. В. Вальков, Т. В. Цивьян; отв. ред. акад. В. Н. Топоров]. - М.: Наука, 2006. - С. 122-124.

28. Пильщиков И. А. Стандарты современного филологического комментария // Комментарий исторического источника: исследования и опыты / отв. ред. М. С. Бобкова. - М.: ИВИ РАН, 2008. - С. 36-45.

29. Плетнев Р. В. «Сердцем мудрые»: (О «старцах» у Достоевского) // Вокруг Достоевского: в 2 т. / сост., вступ. ст. М. Магидовой; коммент. М. Магидовой при участии П. Е. Фокина. - М.: Рус. путь, 2007. - Т. 1: О Достоевском: сб. ст. / под ред. А. Л. Бема. - Прага, 1929 / 1933 / 1936. - С. 251-263.

30. Рейтблат А. И. Комментарий в эпоху Интернета: (Методологические аспекты) // Новое литературное обозрение. - 2004. — № 66. - С. 82-90.

31. Смирнов С. В. По поводу реального комментария к произведениям Н. А. Некрасова // Некрасовский сборник / под ред. А. М. Березкина, Б. В. Мельгунова, М. Ю. Степиной. - СПб.: Наука, 2008. - Т. 14. C. 239-245.

32. Тарасова Н. А. Фаустовская сцена в романе Достоевского «Подросток» // Русская литература. - 2010. - № 1. - С. 171-187.

33. Тарасова Н. А. «Дневник писателя» Ф. М. Достоевского за 1876-1877 годы: критика текста. - М.: Квадрига-МБА, 2011. - 392 с.

34. Тер-Минасова С. Г. Язык и межкультурная коммуникация. - 3-е изд. М.: Изд-во МГУ, 2008. - 352 с.

35. Тименчик Р. Д. Монолог о комментарии // Тименчик Р. Д. Что вдруг. Статьи о русской литературе прошлого века. - М.: Гешарим - Мосты культуры, 2008. - С. 587-591. 
36. Тихомиров Б. Н. Религиозные аспекты творчества Ф. М. Достоевского. Проблемы интерпретации, комментирования, текстологии: автореф. дис. ... д-ра филол. наук. - Петрозаводск, 2006. - 42 с.

37. Тихомиров Б. Н. Академический комментарий: цели, задачи, принципы // Достоевский и мировая культура. - СПб.: Серебряный век, 2008. — № 24. - С. 117-126.

38. Тихомиров Б. Н. «А живу в доме Шиля...»: адреса Ф. М. Достоевского в Петербурге, известные и неизвестные. 1837-1881. - СПб.: Серебряный век, 2016. - 152 с.

39. Томашевский Б. В. Писатель и книга: очерк текстологии. - М.: Искусство, 1959. - 279 с.

40. Фокин П. Е. «Женский вопрос» в «Дневнике писателя» 1876-1877 гг. Ф. М. Достоевского // Преображение. - 1998. — № 6. - С. 29-33.

41. Шоломова Т. В. Эстетизация нигилизма в русской литературе XIX века: к вопросу о пространственных и временных границах явления // Общество. Среда. Развитие. - 2015. - № 3. - С. 127-131.

42. Юренева Т. Ю. Западноевропейские естественно-научные кабинеты XVI-XVII веков // Вопросы истории естествознания и техники. 2002. - № 4. - C. 64-78.

43. Mauriès P. Cabinets de curiosités: [Album]. — [Paris]: Gallimard, 2002. — $267 \mathrm{p}$.

44. The origins of museums: The cabinet of curiosities in sixteenth and seventeenth century Europe / ed. by Oliver Impley and Arthur Macgregor. - Oxford: Clarendon press, 1986. $-352 \mathrm{p}$. 
Natalia A. Tarasova

(Saint Petersburg, Russian Federation)

nsova74@mail.ru

\title{
The Problems of the Preparation of a Historical ("Real") Commentary (Based on Dostoevsky's Novel “The Idiot”)
}

\begin{abstract}
The article is devoted to theoretical and practical issues that emerge while preparing the historical ("real") commentary on Dostoevsky's writings. The work studies traditional and modern approaches to commenting of literary texts, provides variants of the classification of linguistic commentaries of different types, and identifies types that are relevant to the study of Dostoevsky's works. In the article, as exemplified in Dostoevsky's novel "The Idiot" (its handwritten and printed texts), the question of the tasks, subject, content and limits of a historical ("real") commentary on literary texts is examined. The problem of the word interpretation is analyzed taking into account the semantic context. The article analyzes the issues of commenting the names of real historical persons and characters, allusions to historical ideas, biblical quotes, literary intertexts, including auto-reminiscences. As a result of the accomplished analysis, the historical ("real") commentary on Dostoevsky's novel "The Idiot" was refined, clarified and supplemented.
\end{abstract}

Keywords: Dostoevsky, Russian literature, problems of commenting on a literary text

About the author: Tarasova Natalia A. - Doctor of Philology, Leading Researcher, The Institute of Russian Literature (Pushkinskiy Dom), Russian Academy of Sciences (nab. Makarova 4, Saint Petersburg, 199034, Russian Federation)

Received: April 5, 2019

Date of publication: September 9, 2019

For citation: Tarasova N. A. The Problems of the Preparation of a Historical ("Real") Commentary (Based on Dostoevsky's Novel "The Idiot"). In: Problemy istoricheskoy poetiki [The Problems of Historical Poetics], 2019, vol. 17, no. 3, pp. 149-185. DOI: 10.15393/j9.art.2019.6181 (In Russ.)

\section{References}

1. Alyokin V. N. Utochneniya $i$ dopolneniya k kommentariyam [Refinements and Additions to the Commentaries]. Available at: http://aljokin-1957.narod. $\mathrm{ru} /$ fan32.html (accessed on March 7, 2019). (In Russ.)

2. Al'tman M. S. Dostoevskiy: Po vekham imen [Dostoevsky: Following the Landmarks of Names]. Saratov, Saratov State University Publ., 1975. 280 p. (In Russ.)

3. Bogdanov K. A. The Game Blind Man's Buff: Plot, Context, Metaphor. In: Bogdanov K. A. Povsednevnost' i mifologiya: Issledovaniya po semiotike 
fol'klornoy deystvitel'nosti [Bogdanov K. A. Everyday Life and Mythology: Studies on Semiotics of the Folklore Reality]. St. Petersburg, Azbuka Publ., 2015, pp. 104-171. (In Russ.)

4. Budanova N. F. Unknown Dostoevsky's Articles on the "Women's Question": (Experience of Attribution). In: Dostoevskiy. Materialy i issledovaniya [Dostoevsky. Materials and Researches]. St. Petersburg, Nauka Publ., 1976, vol. 2, pp. 236-244. (In Russ.)

5. Varlamova D. V. Zhenskiy vopros v zhurnalakh M. M. i F. M. Dostoevskikh "Vremya» $i$ "Epokha»: dis. ... kand. filol. nauk [The "Women's Question" in Magazines of Mikhail and Fedor Dostoevsky "Time" and "Epoch". PhD. philol. sci. diss.]. Moscow, 2017. 158 p. (In Russ.)

6. Vinogradov V. V. Istoriya slov: okolo 1500 slov i vyrazheniy i bolee 5000 slov, s nimi svyazannykh [Words History: About 1500 Words and Expressions and more than 5000 Words Related to Them]. Moscow, The V. V. Vinogradov Russian Language Institute of the RAS Publ., 1999. 1138 p. (In Russ.)

7. Vladimirtsev V. P. A Poetic Bestiary. In: Vladimirtsev V. P. Dostoevskiy narodnyy [Vladimirtsev V. P. National Dostoevsky]. Irkutsk, Irkutsk State University Publ., 2007, pp. 300-315. (In Russ.)

8. Voznesenskaya A. P. The Image of a Nihilist Woman as a Reflection of the Change of the Value Paradigm in Russian Culture of the 19th Century. In: Obshchestvo. Sreda. Razvitie [Society. Environment. Development], 2012, no. 2, pp. 153-156. (In Russ.)

9. Galagan G. Ya. The Problem of "the Best Personalities" in the Creative Heritage of F. M. Dostoevsky (1873-1876). In: Dostoevskiy. Materialy $i$ issledovaniya [Dostoevsky. Materials and Researches]. St. Petersburg, Dmitriy Bulanin Publ., 1996, vol. 12, pp. 99-107. (In Russ.)

10. Gasparov M. L. Yu. M. Lotman and the Problem of Commenting. In: Novoe literaturnoe obozrenie [New Literary Review], 2004, no. 66, pp. 70-74. (In Russ.)

11. Dorofeeva K. V. The Life of St. Avraamy of Galich. In: Vestnik tserkovnoy istorii [Bulletin of Ecclesiastical History], 2011, no. 1/2 (21/22), pp. 5-55. (In Russ.)

12.Dostoevskiy: dopolneniya k kommentariyu [Dostoevsky: Additions to the Commentary]. Moscow, Nauka Publ., 2005. 694 p. (In Russ.)

13. Zakharov V. N. Textual Criticism as Technology. In: Zakharov V. N. Problemy istoricheskoy poetiki: etnologicheskie aspekty [Zakharov V. N. Problems of Historical Poetics: Ethnological Aspects]. Moscow, Indrik Publ., 2012, pp. 205-221. (In Russ.)

14. Zakharov V. N. "Demons": Two Novels, How to Publish. In: Imya avtora Dostoevskiy: ocherk tvorchestva [The Author's Name Is Dostoevsky: An Essay on Creative Works]. Moscow, Indrik Publ., 2013, pp. 317-352. (In Russ.)

15. Isupov K. G. Commentator's Outsideness. In: Voprosy literatury, 2008, no. 2, pp. 6-19. (In Russ.)

16. Kazakova T. A. A Translational Commentary: Structure and Functions. In: Universitetskoe perevodovedenie [University Translation Studies]. St. Petersburg, Philological Faculty of St. Petersburg State University Publ., 2003, vol. 4, pp. 169-178. (In Russ.) 
17. Kasatkina T. A. Kharakterologiya Dostoevskogo. Tipologiya emotsional'no-tsennostnykh orientatsiy [The Characterology of Dostoevsky. The Typology of Emotional Value Orientations]. Moscow, Nasledie Publ., 1996. 336 p. (In Russ.)

18. Kasatkina T. A. The Problems of the "Real" Commenting. In: Novyy mir [New World], 2018, no. 7, pp. 181-198. (In Russ.)

19. Korobeynikova N. N. Ontologiya kommentariya i ego rol'v ponimanii inoyazychnogo khudozhestvennogo teksta: avtoref. dis. ... kand. filol. nauk [The Ontology of Commentary and its Role in Understanding of Foreign Literary Texts. PhD. philol. sci. diss. abstract]. Barnaul, 2006. 22 p. (In Russ.)

20. Krapivin G. N. What did Hegumen Paphnutius Have his Hand in? In: Russkaya literatura, 2014, no. 4, pp. 145-151. (In Russ.)

21. Kuklinova I. A. Studies in France in the 16th-17th Centuries. In: Muzey $v$ sovremennoy kul'ture [A Museum in Modern Culture]. St. Petersburg, St. Petersburg State Academy of Culture Publ., 1997, vol. 147, pp. 24-38. (In Russ.)

22.Kuklinova I. A. Muzei Frantsii XIV-XIX vekov [The Museums of France of the 14th-19th Centuries]. St. Petersburg, St. Petersburg State University of Culture and Arts Publ., 2001, part 1. 148 p. (In Russ.)

23. Likhachev D. S., pri uchastii A. A. Alekseeva i A. G. Bobrova. Tekstologiya na materiale russkoy literatury X-XVII vekov [Textual Criticism Based on the Materials of Russian Literature of the 10th-17th Centuries]. St. Petersburg, Aleteyya Publ., 2001. 758 p. (In Russ.)

24.Lotman Yu. M. Pushkin. St. Petersburg, Iskusstvo-SPb. Publ., 1995. 845 p. (In Russ.)

25. Lotman Yu. M. A Symbol in the System of Culture. In: Lotman Yu. M. Vnutri myslyashchikh mirov. Chelovek - tekst - semiosfera - istoriya [Lotman Yu. M. Inside the Thinking Worlds. Man - Text - Semiosphere History]. Moscow, Yazyki russkoy kul'tury Publ., 1996, pp. 146-160. (In Russ.)

26. Mann Yu. N. V. Gogol: an Academic Commentary in Search of a Genre. In: Problemy tekstologii i editsionnoy praktiki. Opyt frantsuzskikh i rossiyskikh issledovateley [The Problems of the Textual Criticism and Publishing Practice. The Experience of French and Russian Researchers]. Moscow, Ob"edinennoe Gumanitarnoe izdatel'stvo Publ., 2003, pp. 103-111. (In Russ.)

27. Monologues about Commentaries: L. G. Stepanova. In: Tekst $i$ kommentariy: kruglyy stol $k$ 75-letiyu Vyacheslava Vsevolodovicha Ivanova [Text and Commentary: a Round Table Discussion on the Occasion of the 75th Anniversary of Vyacheslav Vsevolodovich Ivanov]. Moscow, Nauka Publ., 2006, pp. 122-124. (In Russ.)

28. Pil'shchikov I. A. The Standards of a Modern Philological Commentary. In: Kommentariy istoricheskogo istochnika: issledovaniya i opyty [A Commentary of a Historical Text: Researches and Experiments]. Moscow, Institute of World History of the Russian Academy of Sciences Publ., 2008, pp. 36-45. (In Russ.)

29. Pletnev R. V. "Wise in Heart": (About the Elders in Dostoevsky's Novels). In: Vokrug Dostoevskogo: 2 tomakh [Around Dostoevsky: in 2 Vols]. Moscow, Russkiy put’ Publ., 2007, vol. 1, pp. 251-263. (In Russ.) 
30. Reytblat A. I. A Commentary in the Internet Age: (Methodological Aspects). In: Novoe literaturnoe obozrenie [New Literary Review], 2004, no. 66, pp. 82-90. (In Russ.)

31. Smirnov S. V. About a "Real" Commentary on the Works of N. Nekrasov. In: Nekrasovskiy sbornik [Nekrasov Digest]. St. Petersburg, Nauka Publ., 2008, vol. 14, pp. 239-245. (In Russ.)

32. Tarasova N. A. A Scene from Faust in Dostoevsky's Novel “The Raw Youth". In: Russkaya literatura, 2010, no. 1, pp. 171-187. (In Russ.)

33. Tarasova N. A. «Dnevnik pisatelya» F. M. Dostoevskogo za 1876-1877 gody: kritika teksta [“A Writer's Diary” by F. M. Dostoevsky (1876-1877): Critique of the Text]. Moscow, Kvadriga-MBA Publ., 2011. 392 p. (In Russ.)

34. Ter-Minasova S. G. Yazyk i mezhkul'turnaya kommunikatsiya [The Language and Intercultural Communication]. Moscow, Moscow State University Publ., 2008. 352 p. (In Russ.)

35. Timenchik R. D. Monologues about Commentaries. In: Timenchik R. D. Chto vdrug. Stat'i o russkoy literature proshlogo veka [Timenchik R. D. Chto vdrug. Articles about Russian Literature of the Last Century]. Moscow, Gesharim - Mosty kul'tury Publ., 2008, pp. 587-591. (In Russ.)

36. Tikhomirov B. N. Religioznye aspekty tvorchestva F. M. Dostoevskogo. Problemy interpretatsii, kommentirovaniya, tekstologii: avtoref. dis. ... d-ra filol. nauk [Religious Aspects of F. M. Dostoevsky's Creativity. The Problems of Interpretation, Commenting, Textual Critisism. PhD. philol. sci. diss. abs tract]. Petrozavodsk, 2006. 42 p. (In Russ.)

37. Tikhomirov B. N. An Academic Commentary: Purposes, Objectives, Principles. In: Dostoevskiy i mirovaya kul'tura [Dostoevsky and World Culture]. St. Petersburg, Serebryanyy vek Publ., 2008, no. 24, pp. 117-126. (In Russ.)

38. Tikhomirov B. N. "A zhivu v dome Shilya...»: adresa F. M. Dostoevskogo $v$ Peterburge, izvestnye i neizvestnye. 1837-1881 ["I Live in the House of Shil...": Addresses of F. M. Dostoevsky in St. Petersburg, Known and Unknown. 1837-1881]. St. Petersburg, Serebryanyy vek Publ., 2016. 152 p. (In Russ.)

39. Tomashevskiy B. V. Pisatel' i kniga: ocherk tekstologii [A Writer and a Book: Essay on Textual Criticism]. Moscow, Iskusstvo Publ., 1959. 279 p. (In Russ.)

40. Fokin P. E. A “Women's Question” in “A Writer's Diary” by F. M. Dostoevsky (1876-1877). In: Preobrazhenie [Transfiguration], 1998, no. 6, pp. 29-33. (In Russ.)

41. Sholomova T. V. Aestheticization of Nihilism in the Russian Literature of the 19th Century: More on the Question of Spatial and Temporal Boundaries of the Phenomenon. In: Obshchestvo. Sreda. Razvitie [Society. Environment. Development], 2015, no. 3, pp. 127-131. (In Russ.)

42. Yureneva T. Yu. The Western European Natural Science Cabinets of the 16th-17th Centuries. In: Voprosy istorii estestvoznaniya i tekhniki [Questions of the History of Science and Technology], 2002, no. 4, pp. 64-78. (In Russ.)

43. Mauriès P. Cabinets de curiosités: (Album) [Cabinets of Curiosities: (Album)]. Paris, Gallimard Publ., 2002. 267 p. (In French)

44. The Origins of Museums: The Cabinet of Curiosities in Sixteenth and Seventeenth Century Europe. Oxford, Clarendon press Publ., 1986. 352 p. (In English) 